\title{
Coiled-Coil Domain-Containing Protein 6
}

National Cancer Institute

\section{Source}

National Cancer Institute. Coiled-Coil Domain-Containing Protein 6. NCI Thesaurus. Code C17811.

Coiled-coil domain-containing protein $6(474 \mathrm{aa}, \sim 53 \mathrm{kDa})$ is encoded by the human CCDC6 gene. This protein may be involved in tumor suppression. 